\title{
NOTES ON KEY TERMS
}

In a book intended for use by multiple audiences, there are inevitably a few terms that benefit from clarification. In particular, the terms bar or bat mitzvah and Torah take on a range of meanings, so I clarify them here. Other terms are defined in the text.

Literally, bar mitzvah combines Aramaic and Hebrew to mean "son of the commandment(s)", with the plural being b'nai mitzvah for a group that includes at least one male. Bat mitzvah is the corresponding term for a girl ("daughter of the commandment[s])," with the plural for an all-female group being b'not mitzvah. These translations show that the phrases refer to a person or people, rather than to a ritual. Indeed, that is one usage: a boy becomes a bar mitzvah on turning thirteen; a girl becomes a bat mitzvah at thirteen in liberal American Judaism or at twelve in Orthodox Judaism. Yet these definitions expanded over time.

Bar or bat mitzvah also refers to the ritual in which the boy or girl participates, which symbolically represents a new status. In common parlance, it often refers to the party celebrating that symbolic moment. It also serves as all-inclusive term that covers the entire event, from the beginning of the service to the end of the celebration.

In this book, I use bar or bat mitzvah as an adjective: bar or bat mitzvah student or child describes the individual; bar or bat mitzvah service, ritual, or performance describes the ceremony itself; bar or bat mitzvah celebration describes the party; and bar or bat mitzvah event describes the entire day. B'nai or b'not mitzvah also appear where plurals are appropriate.

Torah, too, has several meanings. "The Torah" refers to the Five Books of Moses or the Pentateuch, handwritten on a scroll. The content encapsulates the fundamental narratives, values, and practices of Judaism, while the scroll itself is a concrete and sacred symbol that represents the heart of Judaism. "Torah" (without the definite article) often has a more general meaning, encompassing Jewish learning through the millennia to the present. Though Jews of all denominations use this broader definition of Torah, the phrase "Torah Judaism" refers to Orthodox practice that follows rules (Halakhah) derived from this definition of Torah.

In this book, I use "the Torah" when referring to the Five Books of Moses, "the Torah scroll" when discussing the scroll itself, and "Torah" when discussing general Jewish learning. 

COMING OF AGE IN JEWISH AMERICA 
